\title{
O PESO E A PLUMA
}

Marcelo Rocha Bentes ${ }^{1}$

Naquele fim de tarde ela iluminou seus olhos contemplando o horizonte incandescente.

Seriam pequenas eternidades ou plumas passageiras?

No apartamento pesado a chuva corria triste na janela. Ele chorou.

Ontem ela sonhou com quimeras coloridas, e despertou sorrindo.

O nevoeiro tem embaçado os sonhos dele.

Olhando para a Lua, ela lembrou-se da primeira vez que andaram de mãos dadas na praia: foi numa noite prateada. O despertador não respeita a poesia. Ela suspirou levemente.

Nessa mesma noite, por alguns segundos ele sentiu o suave calor das mãos dela; e logo veio a penumbra.

E os beijos com gosto de amor eterno? Ela ainda consegue lembrar-se. Ele sente a boca seca.

Dia desses ela colheu lírios no seu jardim.

Ele acordou sentido o perfume dessas flores. Pulou da cama. Saiu caminhando afoitamente pelas ruas, seguindo o aroma; mas logo foi-se a essência e ficaram os cheiros dos carros. Ele sentou-se na sarjeta e desejou cair num sono profundo. Faz tanto tempo que não a vê. E se esquecer até do nome dela?

— Sandrine Kelen! Sandrine Kelen! Ele repetiu angustiado.

Ela não esqueceu o nome dele.

- Ruan Lúcio, ela diz com doçura nos lábios.

Às vezes, ela ainda consegue vê-lo, mas não consegue tocá-lo.

Foi numa noite de primavera que o conheceu. E numa noite de tempestade ele partiu. O que aconteceu? Ela não entende. Ele também não.

Ela está num sítio. Ele está na cidade.

Ela está vendo beija-flores namorando, e há rosas enciumadas. Ele vê carros fervendo vidas.

Há pesos e plumas misturando-se em suas vidas distantes.

- Lembras a primeira vez que disse que te amo? - ele falou como se ela estivesse ouvindo.

1E-mail: marceloo.roocha@gmail.com 
- Vi infinitos no seu olhar, e você segurou as minhas mãos para sempre e disse que me amava - ela respondeu como se tivesse ouvido ele perguntar.

Quem há de entender os insondáveis mistérios da vida? Derramam-se como cachoeiras silenciosas sobre as nossas vidas. Quantos pores do Sol cabem no horizonte? Quantas Luas cabem num poema? Quantas indagações perpassam a vida?

Em dias límpidos podemos ver as nuvens refletindo-se perfeitamente no espelho dos rios; e isso é mais lindo do que conseguimos entender.

Há mais poder num relâmpago do que em qualquer ação humana ou de máquinas. Vulcões são as gargantas da Terra. E tantas vezes têm gritado as dores da Terra. Larva é lágrima.

O real e o imaginário pairam constantemente em nossas mentes e olhares. Será real o que realmente sentirmos.

Ontem ela fez pipoca doce. Ele adora. Ele saboreou o sorvete de leite condensado com frutas. Ela ama.

Ela anda relendo um Romance que ele adora. Ele tem declamado poemas que ela ama.

- Seja flor.

Seja amor.

Seja cor.

Seja tão somente meu amor...

Diz a estrofe de um dos poemas que ele declama. Enquanto lê o Romance, ela lembrase do inconformismo dele com relação ao destino de um dos personagens.

- Mas se não for assim a história não fará sentido - ela dizia pra ele.

- Eu sei, amor, mas é difícil lidar com a morte de um personagem que amamos respondia ele.

Então ela o abraçava, e era como se os seus braços saíssem de dentro das páginas do livro. E assim iam se amando: unindo gostos, saberes e momentos. Respeitando-se e compreendendo-se constantemente.

Discutiam? Às vezes sim, mas logo faziam as pazes. Ela simplesmente era tudo pra ele, e ele era absolutamente tudo pra ela. Iam casar? Suas almas e corpos já estavam casados muito antes de nascerem.

Vemos balões subindo e sabemos que ao atingirem uma certa altura o gás no seu interior se expandirá tanto, e de repente a fina camada do balão será rompida. Há existências sublimes e frágeis. Ela vê pássaros bailando numa ópera celestial. Ele fecha os olhos e também os vê. 
Há 3 anos ela adormeceu e num sonho maravilhoso o conheceu. Nesse mesmo sonho, ele a encontrou, e logo soube que ela era o grande amor da sua vida.

Logo se amaram, pois assim estavam destinados. O imaginário era o real desse amor.

Em um lado da cidade ela sonhava, e no outro lado da cidade ele a encontrava no seu sonho. Por 2 anos e meio se amaram intensamente sem nunca se encontrarem no mundo que supostamente é o real.

Real é o que sentimos. Bem sabem que foi tudo real: cada olhar, toque, carícia, beijo, confidências, risos, lágrimas e infinitudes.

Numa noite sombria não conseguiram mais encontrar-se nos sonhos; e esse é o único lugar aonde desejam realmente se encontrar, pois esse é o seu mundo real.

O peso e a pluma perpassando suas existências. Sabem que a saudade pode ser um peso infinito, e as plumas podem trazer lembranças adocicadas.

Já é madrugada, e no sítio ela adormece; e na cidade o sono também o carregou para um mundo aonde ela o espera. Desejam ardentemente que o sono seja eterno; e que os sonhos os conduzam novamente para a estrada do amor onde se abraçaram pela primeira vez. E desta vez não se soltarão jamais. 